\title{
ANALISIS RASIO PROFITABILITAS PT. BANK PERKREDITAN RAKYAT JORONG KAMPUNG TANGAH PARIAMAN CABANG PADANG
}

\author{
Rossi Putri Andanis, Jhon Fernos \\ Akademi Keuangan dan Perbankan "Pembangunan" \\ rossyputriandanis@gmail.com \\ jhonfernos@akbpstie.ac.id
}

\begin{abstract}
The purpose of this study was to find out how the profitability rasio PT. BPR Jorong Kampung Tangah Cabang Padang. The research method used is the method of data analysis qualitative and quantitative. The tipe of data used is secondary data obtained from Financial Services Authority's Report and rural bank (BPR) publication reports for thr period 2015 - 2017. The results of this study indicate that the bank ROA level is still in an unhealthy position. ROE level also shows bank in unhealthy condition in generating net income, in the BOPO position has decreased but according to BI BOPO standards are still in the good category. While the bank NPM level has increased, which means the bank is said to be well at generating net income.
\end{abstract}

Keywords : Profitability, ROA, ROE, and NPM

\section{PENDAHULUAN}

Pengukuran taraf efektivitas manajemen yang ditunjukkan oleh laba yang dihasilkan dari perdagangan dan dari penerimaan investasi, dapat dilakukan dengan mengetahui seberapa besar rasio profitabilitas yang dimiliki. Dengan menanggapi rasio profitablitas yang di miliki perusahaan dapat mengawasi perkembangan peusahaan dari waktu ke waktu (Martono 2002).

Menurut Undang-Undang Nomor 10 Tahun 1998 Tentang Perbankan ada 2 jenis bank yaitu bank umum dan bank perkreditan rakyat. Bank umum adalah suatu bank yang kegiatan usahanya dilakukan dengan cara konvensional dan didasarkan prinsip syariah yang kegiatannya memberikan jasa lalu lintas pembayaran. Untuk mendapatkan suatu gambaran tentang financial suatu bank, perlu mengeluarkan analisa atau pemahaman terhadap data financial dari bank yang berkepentingan, dimana data financial itu tercermin didalam laporan keuangan.

Menurut Ikatan Akuntansi Indonesia (IAI), laporan keuangan mempunyai tujuan untuk memberikan informasi tentang posisi keuangan, kinerja dan arus kas perusahaan yang bermanfaat bagi sebagian besar kalangan pengguna laporan dalam 
rangka membuat keputusan-keputusan ekonomi serta menunjukkan pertanggung jawaban manajemen atas pengguna sumber-sumber data yang dipercayakan kepada mereka (Ekonomi et al. 2017).

Dalam era globalisasi sekarang ini fungsi bank sangat bermakna bagi masyarakat indonesia, karena perbankan bertujuan untuk penyusunan nasional dalam meningkatkan gambaran luas tentang kebutuhan konsumen yang semakin meningkat dengan perkembangan ini, kebutuhan konsumen juga semakin bertambah akan tetapi pada perkembangan itu menyebabkan munculnya pesaing yang begitu ketat.

Profitabilitas adalah kemampuan suatu bank dalam menghasilkan laba selama periode tertentu, juga bertujuan untuk mengukur tingkat efektifitas manajemen dalam menjalankan operasional perusahaannya (Qoroni 2015).

Laporan keuangan merupakan hasil akhir dari proses akuntansi yang me;iputi dua laporan utama yakni neraca dan laporan laba/rugi (Kasmir 2016).

Menurut (Afriyeni and Fernos 2018)Return On Assets (ROA) merupakan rasio keuangan yang dapat digunakan untuk mengetahui dan mengukur seberapa besar kemampuan bank dalam memperoleh pendapatan dengan memanfaatkan semua harta yang dimilikinya. Semakin tinggi ROA pada bank, maka akan semakin baik posisi bank tersebut jika dipandang dari segi penggunaan asetnya.

Return On Equity (ROE) merupakan alat analisis yang digunakan untuk menunjukkan kemampuan perusahaan dalam menghasilkan laba dari hutang yang dimiliki dengan membandingkan laba bersih dan modal (Sukses, Tbk, and Ilmiah 2016).

BOPO (Biaya Operasional dan Pendapatan Operasional) adalah rasio efisiensi bank yang mengukur beban opersional terhadap pendapatan operasional. Semakin tinggi nilai BOPO maka semakin tidak efisien operasi bank (RAVIKA 2011).

Net Profit Margin (NPM) adalah rasio yang menggambarkan tingkat keuntungan (laba) yang diperoleh bank dibandingkan dengan pendapatan yang diterima dari kegiatan operasionalnya (Fernos 2017).

Rasio ini membandingkan antara keuntungan bersih setelah pajak terhadap penjualan bersih. Jikarasio semakin tinggi maka menunjukkan kemampuan perusahaan dalam mencapai laba yang tinggi pada tingkat penjualan tertentu. Apabila rasio ini rendah menunjukkan penjualan yang terlalu rendah untuk tingkat biaya tertentu, atau biaya yang terlalu tinggi untuk penjualan tertentu, atau kombinasi dari kedua hal tersebut.

PT. Bank Perkreditan Rakyat Jorong Kampung Tangah Cabang Padang merupakan salah satu bank yang ada di kota padang, tepatnya terletak di Jl. Adinegoro Km. 15 Lubuk Buaya Padang. BPR ini harus memperhatikan tingkat profitabilitas yang dimiliki agar dapat mencapai suatu keuntungan yang lebih dimasa yang akan datang. Salah satu indikator yang digunakan untuk menilai keberhasilan atau kegagalan BPR dalam mencapai tujuan tersebut yaitu laporan kinerja keuangan bank yang telah dicapai. Berikut perkembangan Rasio Profitabilitas pada PT. BPR Jorong Kampung Tangah Cabang Padang pada Desember 2015 - Desember 2017. 


\section{Tabel 1 \\ Perkembangan Rasio Profitabilitas \\ Tahun $2015-2017$}

(Rp.000)

\begin{tabular}{llll}
\hline \multicolumn{1}{c}{ Indikator } & \multicolumn{1}{c}{ Des 2015 } & \multicolumn{1}{c}{ Des 2016 } & Des 2017 \\
\hline Return On Assets & $4,27 \%$ & $2,72 \%$ & $3,26 \%$ \\
Return On Equiry & $19,95 \%$ & $14,15 \%$ & $11,20 \%$ \\
Biaya Operasional & $80,22 \%$ & $79,35 \%$ & $75,20 \%$ \\
Net Profit Margin & $27,07 \%$ & $17,22 \%$ & $21,02 \%$ \\
\hline
\end{tabular}

Sumber: Data Olahan, 2019

Berdasarkan tabel diatas secara umum dapat dilihat bahwa laporan keuangan PT. BPR Jorong Kampung Tangah Cabang Padang pada bulan Desember tahun 2015-2017 pada rasio profitabilitas masih berfluktuasi. Dimana dapat dilihat ROA pada bulan Desember 2015-Desember 2016 mengalami penurunan, sedangkan pada bulan Desember 2016-Desember 2017 mengalami kenaikan beberapa persen. ROE pada bulan Desember 2015-Desember 2017 mengalami penurunan sampai bebebrapa persen. BOPO pada bulan Desember 2015-Desember 2017 mengalami penurunan, tetapi menurut standar BI BOPO termasuk kategori baik. NPM pada bulan Desember 2015-Desember 2016 mengalami penurunan, sedangkan pada bulan Desember 2016Desember 2017 mengalami kenaikan dibandngkan dengan tahun sebelumnya.

Berdasarkan masalah diatas, maka penulis tertarik untuk melakukan penelitian dengan judul "Analisis Rasio Profitabilitas PT. Bank Perkreditan Rakyat Jorong Kampung Tangah Cabang Padang”. Berdasarkan uraian tersebut, maka tujuan penelitian ini yaitu untuk mengetahui bagaimana rasio profitabilitas yang diukur dari Return On Asset (ROA), Return On Equity (ROE), Biaya Operasional (BOPO), dan Net Profit Margin (NPM) yang ada pada PT. Bank Perkreditan Rakyat Jorong Kampung Tangah Cabang Padang bulan Desember 2015 - Desember 2017. Rumusan Masalah diatas yaitu berdasarkan tingkat profitabilitas pada PT. BPR Jorong Kampung Tangah Cabang Padang periode Desember 2015, Desember 2016, dan Desember 2017.

\section{LANDASAN TEORI \\ Pengertian Bank}

Dalam UU Perbankan ayat 1 pasal 2 No.10 tahun 1998 perubahan UU No. 7 tahun 1992 " bank adalah suatu badan usaha yang bertugas menghimpun dana dari masyarakat dalam bentuk simpanan (deposito, tabungan, giro) dan menyalurkan kepada masyarakat dalam bentuk kredit atau bentuk - bentuk lainnya dalam rangka meningkatkan taraf hidup masyarakat banyak.

Bank adalah badan usaha yang kegiatannya menghimpun dana dari masyarakat dalam bentuk simpanan, kemudian mengalokasikannya kembali untuk memperoleh keuntungan serta menyediakan jasa - jasa dalam lalu lintas pembayaran (Nopian and Chasanah 2014). Suatu jenis lembaga keuangan yang melaksanakan 
berbagai macam jasa seperti memberikan pinjaman, mengedarkan mata uang, pengawasa terhadap mata uang, bertindak sebagai tempat penyimpanan barang barang berharga, membiayai usaha perusahaan - perusahaan.

\section{Pengertian BPR}

Dalam undang - undang perbankan pasal 1 ayat 2 No. 10 tahun 1998 tentang perubahan undang - undang No. 7 tahun 1992 disebutkan bahwa Bank Perkreditan Rakyat adalah bank yang melaksanakan kegiatan usaha secara konvensional atau berdasarkan prinsip syari'ah dalam kegiatannya tidak memberikan jasa lalu lintas pembayaran. Kegiatan utama usaha Bank Perkreditan Rakyat ini tujuan untuk menanggapi usaha mikro kecil dan menengah pada masyarakat di daerah pedesaan dan di kota kecil. Bentuk kegiatan Bank Perkreditan Rakyat sendiri berupa perseroan terbatas, perusahaan daerah ataupun dalam bentuk instansi.

\section{Asas, Tujuan, Fungsi dan Sasaran Bank Perkreditan Rakyat}

BPR berasakan demokrasi ekonomi adalah suatu sistem ekonomi indonesia yang dijalankan sesuai dengan pasal 33 UUD 1945 yang memiliki 8 ciri positif sebagai pendukung dan 3 ciri negatif yang harus dihindari (free fight liberalisme, etatisme dan monopoli).

Tujuan BPR adalah membantu pelaksanaan pembangunan nasional dalam rangka menambahkan pemerataan, pertumbuhan ekonomi, dan stabilitas ke arah peningkatan kesejahteraan rakyat banyak (Ratna, Ari, and Hartono 2015). Fungsi Bank Perkreditan Rakyat untuk memberikan suatu layanan kepada masyarakat untuk menerima tabungan mereka dalam bentuk deposito berjangka, tabungan, dan bentuk lainnya yang dipersamakan dengan itu. Untuk memberikan kredit, menyediakan pembiayaan bagi nasabah yang berdasarkan prinsip bagi hasil sesuai dengan ketentuan yang ditetapkan dalam peraturan pemerintah. Menempatkan dananya dalam bentuk Sertifikat Bank Indonesia (SBI), deposito berjangka, sertifikat deposito.

Sasaran BPR adalah melayani kebutuhan orang tani, penjaga, pelaut, penjual, pengusaha kecil, karyawan dan pensiun, karena sasaran ini belum terjangkau oleh bank umum dan untuk lebih mewujudkan pemerataan layanan perbankan, pemerataan kesempatan berusaha, pemerataan pendapatan, agar mereka tidak jatuh ketangan para petugas tukang riba.

\section{Pengertian laporan Keuangan}

Laporan keuangan ini disusun dan ditafsirkan untuk kepentingan manajemen dan pihak lain yang menaruh perhatian atau mempunyai kepentingan dengan data keuangan perusahaan tersebut. Sama seperti lembaga keuangan yang lain, bank juga mempunyai beberapa jenis laporan keuangan yang disajikan sesuai dengan Standar Akuntansi Keuangan, jenis - jenis laporan keuangan sebagai berikut (Kasmir 2016):

\section{Neaca}

Neraca adalah laporan keuangan yang menunjukkan posisi keuangan bank pada tanggal tertentu, yang dimaksud dengan posisi keuangan adalah posisi aktiva (harta) pasiva (kewajiban dan ekuitas) suatu bank. Dalam laporan neraca aktiva terletak disebelah kiri dan pasiva terletak di sebelah kanan (Setiyono and Mifthakul 2014). 
2. Laporan Komitmen dan Kontijensi

Laporan Komitmen dan kontijensi adalah suatu hubungan atau kontrak yang berbentuk janji atau tidak dapat dibatalkan secara satu pihak dan harus dilaksanakan apabila suatu persyaratan yang disepakati bersama terpenuhi. Kontijensi merupakan transaksi yang paling banyak ditemukan dalam kegiatan bank sehari-hari..

3. Laporan Laba Rugi

Laporan Laba Rugi merupakan laporan keuangan bank yang menggambarkan hasil usaha bank dalam suatu periode tertentu.

4. Laporan Arus kas

Laporan Arus Kas adalah suatu laporan keuangan yang menunjukkan perincian dari arus kas masuk dan keluar suatu perusahaan pada periode tertentu.

5. Catatan atau Laporan Keuangan

Catatan atau Laporan Keuangan adalah hasil akhir dari proses pencatatan dan perhitungan yang berisi ringkasan dari transaksi - transaksi keuangan selama periode tertrntu.

6. Laporan Keuangan Gabungan dan Kosoloasi

Laporan keuangan gabungan dan merupakan laporan dari cabang bank yang bersangkutan, baik yang ada didalam maupun diluar negeri. Sedangkan laporan keuangan kosoloasi merupakan laporan bank yang bersangkutan dengan anak perusahaan.

\section{Pengertian Profitabilitas}

profitabilitas merupakan kemampuan perusahaan dalam menghasilkan laba. Dalam beroperasi untuk menghasilkan laba tersebut perusahaan menggunakan sumber dana internal yakni dari modal pemilik dan laba ditahan maupun dari eksternal yakni sumber dana yang berasal dari pinjaman pihak lain (Sutrisno 2014).

Kemampuan perusahaan dalam menghasilkan laba dengan semua asset yang dipunyai disebut sebagai Return On asset (ROA), sedangkan kemampuan perusahaan dalam mencapai laba dengan modal sendiri disebut sebagai Return On Equity(ROE), profitabilitas bisa juga diukur dengan Net Profit Margin (NPM) yakni kemampuan menghasilkan laba dengan hasil penjualan penghasilan.

\section{METODE PENELITIAN}

Dalam pengumpulan data untuk melakukan penelitian ini digunakan metode sebagai berikut :

1. Metode pengumpulan data

a. Studi lapangan (Field Research)

Peninjauan langsung ke objek penelitian yang dipilih untuk meneliti hasil data primer. Penelitian langsung ke lapangan ini akan membantu penulis untuk melengkapi data yang diperlukan. Adapun cara riset lapangan ini adalah dengan mewawancarai pihak-pihak yang berkepentingan dalam kondisi ini perusahaan atau instansi yang terkait. 
b. Studi perpustakaan (Library research)

Penelitian yang dapat dilakukan ke perpustakaan untuk membaca beberapa buku-buku ilmiah dan tulisan-tulisanyang berhubungan dengan pembahasan yang akan dilakukan.

2. Metode analisa data

Dalam menganalisis data, penulis akan menggunakan analisis data kualitatif dan kuantitatif. Dimana kualitatif memahami dan menjelaskan data yang diteliti selama penelitian berlangsung, sedangkan kuantitatif menganalisis perhitungan tingkat profitabilitas pada PT. BPR Jorong Kampung Tangah Cabang Padang.

\section{HASIL DAN PEMBAHASAN}

Berdasarkan data keuangan PT. BPR Jorong Kampung Tangah Cabang Padang yang telah diperoleh, selanjutnya dilakukan perhitungan rasio keuangan dengan 4 indikator. Berikut perhitungan rasio keuangan tersebut.

1. Return On Asset (ROA)

Return On Asset adalah perbandingan laba sebelum pajak dalam 12 bulan terakhir terhadap rata-rata volume dalam periode yang sama. Semakin besar ROA suatu bank, maka semakin besar jug tingkat keuntungan yang dicapai bank tesebut dan semakin baik juga posisi bank tersebut dari penggunaan asset (Setiyono and Mifthakul 2014). Dalam kerangka penilaian kesehatan bank, BI akan memberikan score maksimal 100 (sehat) apabila bank memiliki ROA lebih dari 1,5\%. Berdasarkan data yang diperoleh Return On Asset BPR Jorong Kampung Tangah Cabang Padang bulan Desember 2015 - Desember 2017 ditunjukkan pada tabel dibawah ini.

Tabel 2

Perhitungan ROA PT. BPR Jorong Kampung Tangah Cabang Padang Bulan Desember 2015 - bulan Desember 2017

(Rp.000)

\begin{tabular}{cccc}
\hline Komponen & Des 2015 & Des 2016 & Des 2017 \\
\hline $\begin{array}{l}\text { Return On Asset } \\
\text { a. Laba bersih sebelum } \\
\quad \text { pajak }\end{array}$ & 1.097 .646 & 830.432 & 1.353 .020 \\
b. Total aktiva & 25.707 .588 & 30.512 .806 & 41.466 .563 \\
\hline
\end{tabular}

Sumber : Data Olahan

Dengan Formula

ROA $=\frac{\text { Laba Sebelum Pajak }}{\text { Total Aktiva }} \times 100 \%$

Tahun 2015

$\mathrm{ROA}=\frac{1.097 .646}{25.707 .588} \times 100 \%=4,27 \%$ 
Artinya rasio ROA PT. BPR Jorong Kampung Tangah Cabang Padang pada bulan Desember 2015 nilai ROA sebesar 4,27\%, bulan Desember 2016 nilai ROA sebesar 2,72\%, dan bulan Desember 2017 nilai ROA sebesar 3,26\%. Jadi dari bulan Desember 2015 sampai bulan Desember 2016 mengalami penurunan, walaupun demikian kinerja PT. BPR Jorong Kampung Tangah Cabang Padang tetap baik karena nilai nya masih diatas rata - rata penilaian BI. Jika ROA semakin rendah bank tidak akan bisa beroperasi dengan efektif dan efisien dalam memanfaatkan asset yang dimilikinya dalam menghasilkan keuntungan.

2. Return On Equity (ROE)

Return On Equity merupakan kemampuan perusahaan dalam menghasilkan keuntungan dengan modal sendiri yang dimiliki (Hanafie n.d.). Bahwa Return On Equity merupakan rasio yang mengukur kemampuan suatu perusahaan dalam menghasilkan laba bersih dari modal sendiri yang digunakan oleh peusahaan. Menurut standar BI ROE adalah lebih dari $12 \%$ (baik). Berdasarkan data yang diperoleh Return On Equity BPR Jorong Kampung Tangah Cabang Padang selama bulan Desember 2015-Desember 2017 ditunjukkan pada tabel dibawah ini.

\section{Tabel 3}

Perhitungan ROE BPR Jorong Kampung Tangah Cabang Padang Bulan Desember 2015 - Desember 2017

(Rp.000)

\begin{tabular}{cccc}
\hline Komponen & Des 2015 & Des 2016 & Des2017 \\
\hline $\begin{array}{l}\text { Return On Equity } \\
\text { a. Laba bersih setelah }\end{array}$ & 997.640 & 707.588 & 1.119 .585 \\
$\quad \begin{array}{l}\text { pajak } \\
\text { b. Modal sendiri }\end{array}$ & 5.000 .000 & 5.000 .000 & 10.000 .000 \\
\hline
\end{tabular}

Sumber : Data Olahan

Dengan Formula

$\mathrm{ROE}=\frac{\text { Laba Bersih Setelah Pajak }}{\text { Modal Sendiri }} \times 100 \%$

Tahun 2015

$\mathrm{ROE}=\frac{997.640}{5.000 .000} \times 100 \%=19,95 \%$

Artinya rasio ROE BPR Jorong Kampung Tangah Cabang Padang pada bulan Desember 2015 nilai ROA sebesar 19,95\%, bulan Desember 2016 nilai roe sebesar 14,15\%, dan bulan Desember 2017 nilai ROE sebesar 11,20\% mengalami penurunan, sehingga kemampuan bank dalam menghasilkan laba bersih dari modalnya rendah.

3. Biaya Operasional dan Pendapatan Operasional (BOPO)

Rasio biaya operasional menunjukkan perimbangan antara biaya operasional dan pendapatan operasional. Semakin kecil BOPO menunjukkan semakin 
efisien bank dalam menjalankan aktivitas usahanya. Bank yang sehat rasio BOPO-nya kurang dari Rp. 1.00 sebaliknya bank yang kurang sehat rasio BOPO-nya lebih dari Rp. 1.00. semakin tinggi biaya pendapatan maka bank menjadi tidak efisien (Fernos 2017). Berdasarkan data yang diperoleh biaya operasional (BOPO) BPR Jorong Kampung Tangah Cabang Padang selama bulan Desember 2015 - Desember 2017 ditunjukkan pada tabel dibawah ini.

\section{Tabel 4}

Perhitungan Biaya Operasional BPT Jorong Kampung Tangah Cabang Padang

Bulan Desember 2015 - Desember 2017

(Rp.000)

\begin{tabular}{lrcc}
\hline \multicolumn{1}{c}{ Komponen } & Des 2015 & Des 2016 & Des 2017 \\
\hline Total Beban Operasional & 2.956 .240 & 3.259 .410 & 4.004 .360 \\
Total Pendapatan & 3.684 .746 & 4.107 .383 & 5.324 .297 \\
Operasional & & & \\
\hline
\end{tabular}

Sumber : Data Olahan

Dengan Formula

$\mathrm{BOPO}=\frac{\text { Total Beban Operasional }}{\text { Total Pendapatan Operasional }} \times 100 \%$

Tahun 2015

$\mathrm{BOPO}=\frac{2.956 .240}{3.684 .746} \times 100 \%=80,22 \%$

Artinya rasio BOPO BPR Jorong Kampung Tangah Cabang Padang pada bulan Desember 2015 nilai BOPO sebesar 80.22\%, bulan Desember 2016 nilai BOPO sebesar 79,35\%, dan pada bulan Desember 2017 nilai BOPO sebesar 75,20\%. Semakin kecil semakin efisien bank tersebut mengendalikan biaya operasionalnya, maka keuntungan yang diperoleh bank akan semakin besar.

4. Net Profit Margin (NPM)

Net Profit Margin rasio ini menghitung sejauh mana kemampuan perusahaan dalam menghasilkan laba bersih pada tingkat penjaulan/pendapatan tertentu. Rasio ini bisa diinterprestasikan juga sebagai kemampuan perusahaan menekan biaya-biaya diperusahaan pada periode tertentu (Kusuma 2012). Margin Laba Bersih ini menunjukkan proporsi penjualan yang tersisa setelelah dikurangi semua biaya terkait. Menurut standar BI NPM lebih dari 5\% (baik), berdasarkan data yang diperoleh Net Profit Margin BPR Jorong Kampung Tangah Cabang Padang selama bulan Desember 2015 - Desember 2017 ditunjukkan pada tabel dibawah ini. 
Tabel 5

Perhitungan NPM BPR Jorong Kampung Tangah Cabang Padang Bulan Desember 2015 - Desember 2017

(Rp.000)

\begin{tabular}{llll}
\hline komponen & Des 2015 & Des 2016 & Des 2017 \\
\hline $\begin{array}{l}\text { Laba bersih } \\
\text { setelah pajak }\end{array}$ & 997.640 & 707.588 & 1.119 .585 \\
$\begin{array}{l}\text { Total pendapatan } \\
\text { Operasional }\end{array}$ & 3.684 .746 & 4.107 .383 & 5.324 .292 \\
\hline
\end{tabular}

Sumber : Data Olahan

Dengan Formula

$\mathrm{NPM}=\frac{\text { Laba Bersih Setelah Pajak }}{\text { Total Pendapatan Operasional }} \times 100 \%$

Tahun 2015

$\mathrm{NPM}=\frac{997.640}{3.684 .746} \times 100 \%=27,07 \%$

Artinya rasio NPM BPR Jorong Kampung Tangah Cabang Padang pada bulan Desember 2015 nilai NPM sebesar 27,07\%, bulan Desember 2016 nilai NPM sebesar 17,22\%, dan pada bulan Desemeber 2017 nilai NPM sebesar 21,02\%. Jadi dari bulan Desember 2015 sampai bulan Desember 2016 mengalami penurunan,sehingga kemampuan bank menurun dalam menghasilkan laba bersihnya.

\section{SIMPULAN}

berdasarkan hasil analisis pada bab sebelumnya, gambaran tingkat profitabilitas PT. BPR Jorong Kampung Tangah Cabang Padang bulan Desember 2015 - Desember 2017 ditunjukkan pada tabel sebagai berikut:

Tabel 6

Perbandingan Rasio Profitabilitas PT. BPR Jorong Kampung Tangah

Cabang Padang

Bulan Desember 2015 - Desember 2017

\begin{tabular}{lllll}
\hline \multicolumn{1}{c}{ Rasio } & Des 2015 & Des 2016 & Des 2017 & Rata industri \\
\multicolumn{1}{c}{ Return On Asset } & $4,27 \%$ & $2,72 \%$ & $3,26 \%$ & $100 \%$ \\
Return On Equity & $19,95 \%$ & $14,15 \%$ & $11,20 \%$ & $10 \%$ \\
Biaya Operasional & $80,22 \%$ & $79,35 \%$ & $75,20 \%$ & $0,5 \%$ \\
Net Profit Margin & $27,07 \%$ & $17,22 \%$ & $21,02 \%$ & $5 \%$ \\
\hline
\end{tabular}

Sumber : Data Olahan 
1. Rasio ROA BPR Jorong Kampung Tangah Cabang Padang pada bulan Desember 2015 nilai ROA sebesar 4,27\%, bulan Desember 2016 nilai ROA sebesar 2,72\%. Dan bulan Desember 2017 nilai ROA sebesar 3,26\%. Jadi dari bulan Desember 2015 sampai bulan Desember 2016 mengalami penurunan, sedangkan di bulan Desember 2016 sampai Desember 2017 nilai ROA mengalami kenaikan. Walaupun demikian kinerja BPR Jorong Kampung Tangah Cabang Padang termasuk baik karena nilai ROA masih di atas rata rata penilaian $\mathrm{BI}$, apabila nilai ROA semakin rendah bank tidak akan bisa beroperasi dengan efektif dan efisien dalam memanfaatkan asset yang dimilikinya dalam menghasilkan keuntungan.

2. Rasio ROE BPR Jorong Kampung Tangah Cabang Padang pada bulan Desember 2015 nilai ROE sebesar 19,95\%, pada bulan Desember 2016 nilai ROE sebesar 14,15\%, dan bulan Desember 2017 nilai ROE sebesar 11,20\%, setiap tahun ROE pada BPR Jorong Kampung Tangah Cabang Padang mengalami penurunan sehingga kemampuan bank dalam menghasilkan laba bersih dari modalnya rendah.

3. Rasio BOPO BPR Jorong Kampung Tangah Cabang Padang pada bulan Desember 2015 nilai BOPO sebesar 80,22\%, pada bulan Desember 2016 nilai BOPO sebesar 79,35\%, dan bulan Desember 2017 nilai BOPO sebesar $75,20 \%$, setiap tahun BOPO pada BPR Jorong Kampung Tangah Cabang Padang mengalami penurunan tetapi menurut standar BI BOPO masih dalam kategori baik. Semakin kecil BOPO semakin efisien bank tersebut mengendalikan biaya operasionalnya, maka keuntungan yang diperoleh bank akan semakin besar.

4. Rasio NPM BPR Jorong Kampung Tangah Cabang Padang pada bulan Desember 2015 nilai NPM sebesar 27,07\%, pada bulan Desember 2016 nilai NPM sebesar 17,22\%, dan bulan Desember 2017 nilai NPM sebesar 21,02\%, jadi dari bulan Desember 2015 sampai bulan Desember 2016 mengalami penurunan sehingga kemampuan bank menurun dalam menghasilkan laba bersihnya.

\section{UCAPAN TERIMA KASIH}

Terimakasih penulis sampaikan kepada :

1. Kepada kedua Orang Tua yang selalu memberikan dukungan baik secara moril maupun materil.

2. Direktur AKBP beserta prodi AKBP yang telah memberikan kesempatan kepada penulis untuk melakukan penelitian ini.

3. Dosen pebimbing yang telah memberikan arahan dan bimbingan hingga tugas akhir ini bisa terselesaikan.

4. Pimpinan PT. BPR Jorong Kampung Tangah Cabang Padang yang telah mengizinkan penulis dalam memperoleh informasi beserta pengambilan data.

5. Semua pihak yang telah memberikan dukungan dan bantuannya dalam penyelesian tugas akhir ini 


\section{DAFTAR PUSTAKA}

Afriyeni, A., Fernos, J. (2018). Analisis Faktor-Faktor Penentu Kinerja Profitabilitas Bank Perkreditan Rakyat (BPR) Konvensional Di Sumatera Barat. Jurnal Benefita: Ekonomi Pembangunan, Manajemen Bisnis Dan Akuntansi Volume 3. Nomor 3. Hal. 325-335. http://doi.org/10.22216/jbe.v3i3.3623

Afriyeni, A. (2019). Analisis Laporan Keuangan Berdasarkan Tingkat Profitabilitas Pada PT. Bank Perkreditan Rakyat LPN Tarantang Kabupaten Dharmasraya. https://doi.org/10.17605/OSF.IO/XBF5W

Arifin, I. Z., \& Marlius, D. (2017). Analisis Kinerja Keuangan PT. Pegadaian Cabang Ulak Karang. https://doi.org/10.31227/osf.io/n2peu

Badria, M., \& Marlius, D. (2019). Analisis Rasio Likuiditas Pada PT. Bank Perkreditan Rakyat (BPR) Lengayang. https://doi.org/10.31219/osf.io/esvb7

Fernos, J (2017). Analisis Rasio Profitabilitas Untuk Mengukur Kinerja (Studi Kasus Pada PT. Bank Pembangunan Daerah Provinsi Sumatera Barat. Jurnal Pundi. Vol 01. No 02. https://doi.org/10.31575/jp.v1i2.25

Fitri, H. Y., \& Marlius, D. (2019). Analisis Rasio Likuiditas Pada PT. Bank Perkreditan Rakyat (BPR) Nagari Kasang. https://doi.org/10.31219/osf.io/bcs73

Hanafie, Hadriana. "Analisis Rasio Profitabilitas Untuk Menilai Kinerja Keuangan Pada Industri Tekstil Dan Garmen Yang Terdaftar Di Bursa Efek Indonesia." : 568-82.

Handayani, M., \& Marlius, D. (2017). Analisis Tingkat Kesehatan PT. BPR Batang Kapas. https://doi.org/10.31227/osf.io/bq48z

Kasmir. 2016. "Analisis Laporan Keuangan Dalam Menilai Kinerja Keuangan Industri Semen Yang Terdaftar Di BEI." 1(1): 43-58.

Kusuma, Ratnawati. 2012. "Analisis Rasio Profitabilitas Sebagai Alat Ukur Pada Bank Bni Syariah.” : 1-19.

Martono, Cyrillius. 2002. "Analisis Pengaruh Profitabilitas Industri, Rasio Leverage Keuangan Tertimbang Dan Intensitas Modal Tertimbang Serta Pangsa Pasar Terhadap 'Roa' Dan 'Roe' Perusahaan Manufaktur Yang Go- Public Di Indonesia.” Jurnal Akuntansi dan Keuangan. 
Mustika, S., \& Marlius, D. (2019). Analisa Tingkat Kesehatan Keuangan PT. Bank Perkreditan Rakyat (BPR) Batang Palangki. https://doi.org/10.31219/osf.io/wupyh

Nopian, Puspita Rama, and Mufidatul Chasanah. 2014. "Analisis Tingkat Kesehatan Bank Perkreditan Rakyat." : 34-43.

Putri, Y. A., \& Marlius, D. (2018). Analisis Tingkat Kesehatan Bank Pada PT. Bank Perkreditan Rakyat (BPR) Jorong Kampuang Tangah Pariaman Cabang Padang. https://doi.org/10.31227/osf.io/r98pv

Qoroni, Uwes Al. 2015. "Analisis Pengelolaan Kredit Yang Efektif Guna Meningkatkan Profitabilitas." 26(1): 1-5.

Rahmayeli, D. S., \& Marlius, D. (2017). Analisis Kinerja Keuangan Pada PT. Bank Perkreditan Rakyat (BPR) Batang Kapas Pesisir Selatan. https://doi.org/10.31227/osf.io/sz5db

Ravika, Fauziah. 2011. "Analisis Pengaruh Inflasi Terhadap Tingkat Profitabilitas." (10).

Sari, Y. P., \& Marlius, D. (2019). Analisis Rasio Profitabilitas Pada PT. Bank Negara Indonesia Syariah. https://doi.org/10.31219/osf.io/94bwq

Setiyono, wisnu p, and nur aini Mifthakul. 2014. "Analisis Kinerja Keuangan Perbankan Dengan Menggunakan Metode Camel ( Studi Kasus Pada Performance Of The Bank Using

Sutrisno. 2014. "Pengaruh Profitabilitas Terhadap Kebijakan Dividen Dan Nilai Perusahaan." 10(2): 32-48.

“Undang-Undang Nomor 10 Tahun 1998 Tentang Perbankan.” (Direktur Direktorat Hukum Bank Indonesia): 65. 